DOI: https://doi.org/10.36477/tourismhospcee-2-4

UDC 331.101:3:614.215

\author{
Mitsenko Nataliia \\ Doctor of Economics, Professor, \\ Head of the Department of Economics \\ Lviv Trade and Economic University \\ ORCID: https://orcid.org/0000-0002-0337-8346 \\ Riznyk Dmitro \\ $\mathrm{PhD}$ in Economics \\ ORCID: https://orcid.org/0000-0003-3188-5158
}

\title{
MANAGEMENT OF LABOR MOTIVATION ON ENTERPRISES OF SANATORIUM-RESORT COMPLEX
}

The features are identified and the problematic aspects of labor motivation in the enterprises of the sanatorium and resort complex are singled out. It is emphasized that macroeconomic environment of enterprises is ambiguous, characterized by both positive aspects and signs of a systemic crisis, which affects the formation of prerequisites for their personnel management and labor motivation. It is stressed that there are disproportions in the regional markets for sanatorium and health services. The factors of the internal environment, which act as motivating mechanisms, are revealed. It is concluded that further development of the enterprises of the industry is largely determined by both qualitative personnel provision and the efficiency of personnel work and is directly related to the proper work motivation. The key subjects of motivation are specified, the conceptual principles of labor motivation management at enterprises of the sanatorium-resort complex are improved, for which the characteristics of motivation are supplemented. The attention is paid to the peculiarities of the labor motivation of certain categories of enterprise employees of the sanatorium and resort complex and the need for a targeted approach to the management of the their work motivation. Strategic approaches to motivating work of certain categories of personnel are recommended. The conceptual characteristics of the modern system of enterprises motivation management of the sanatorium and resort complex are singled out. An algorithm for the implementation of this system is proposed for adaptation of the system of work motivation management to business processes.

Keywords: enterprise of sanatorium and resort complex, labor motivation, management of labor motivation, efficiency of management.

Formulation of the problem. Modern trends in the development of society are the intensification of interest in the study of the historical heritage of different peoples, the achievements of world civilization, the desire for mutual enrichment of cultures of different countries. The catalyst of these processes in Ukraine was the growth of population mobility, European integration guidelines for the development of the country's economy, and the entry of Ukraine into the European Union. At the same time, there is an increase in tourist flows both from Ukraine and to Ukraine. The growing interest of the world community in Ukraine will be accompanied by an increase in incoming tourist flows, taking into account, moreover, the unique natural and climatic conditions, hydromineral, balneological and other recreational and medical resources that the country owns and which determine the development of health (medical) tourism.

One of the most important factors in the development of the enterprises in the sanatorium and resort area is their intellectual and human resources that can determine the strategic guidelines for the development of enterprises, to form resource support for the modernization of the material and technical base, to substantiate the updating of the services range, to increase their quality and competitiveness, to ensure the integration of enterprises in domestic and global systems of medical, tourist and leisure business.

At the same time, the formation of intellectual and personnel resources of enterprises of the sanatorium and resort complex and the realization of their potential are largely determined by the effectiveness of the labor motivation management. Currently, the use of modern systems of labor motivation with balanced coverage of its economic, administrative and internal-psychological component, a combination of appropriate methods, instruments and tools at the stages of recruitment, performance of duties and tasks, professional qualification development of personnel, alignment with the peculiarities of economic activities and specifics of the structure of personnel in the sanatorium and resort area are not sufficiently studied, and the results of previous studies have not received a complete practical testing. This hinders the further development of enterprises and the realization of their socio-economic opportunities in the system of tourist-recreational complex and natural-resource potential of Ukraine and, accordingly, actualises the scientific and practical task of improving the management of labor motivation at the enterprises of this branch complex.

Analysis of recent research and publications. Problems of personnel management and work moti- 
vation attracted the attention of many domestic and foreign scholars whose development was the basis (D. McGregor, A. Maslow, F. Hertzberg, D. McClelland, V. Vroom, S. Adams, L. Porter, E. Lawler and other) and developed the theory of motivation significantly: D. Bogynia, P. Buryak, V. Gerchikov, O. Grishnova, N. Yesinova, H. Zavinovska, A. Kolota, R. Krapgam, A. Laurent, E. Libanova, T. Lobanova, V. Nyizhnik, O. Novikova, M. Semikina, R. Hilla, G. Schreder and others. Theoretical and methodical aspects of the management of the enterprises functioning and development of the sanatorium and resort complex are the subject of active scientific discussions by Y. Alekseyeva, N. Vedmid, A. Vetitneva, N. Vlashchenko, I. Grodzinska, I. Dyshlovoi, V. Kalytyuk, N. Necheva, O. Nikitina, M. Oklander, V. Semenova, T. Tkachenko, S. Harichkova, O. Shaptala and other scientists. The study of published works and practices of economic activity shows insufficient coverage of issues related to the application of modern methods of assessment and the theoretical and methodological support for the management of labor motivation at the enterprises of the sanatorium and resort complex, which actualizes the need for further research of the peculiarities, preconditions and determinants of the management of labor motivation in in this sector of the economy.

The purpose of the study is to develop theoretical and methodological approaches, to systematize the results of analysis and to identify the application instruments and tools for managing the motivation of enterprises labor of the sanatorium and resort complex. The object of research is the process of managing the motivation of labor at the enterprises of the sanatorium and resort complex, characterized by continuity, dynamism and strategic orientation.

Presentation of the main research material. To determine the determinants and prerequisites for effective management of labor motivation, we analyzed the main theories of motivation: the initial (D. McGregor), meaningful (A. Maslow, F. Hertzberg, D. McClelland), procedural (V. Vroom, L. Porter, E. Lauler), as well as works by such contemporary scholars as D. Bogynia (2003), V. Grinyova (2007), I. Gruzina (2007), V. Daniuk (2017), A. Kolot (2017), T. Lobanova (2018), V. Nyzhnik (2011), V. Parsyak (2003), V. Petyuch (2017), L. Potyomkin (2011), M. Semikina (2003), O. Handii (2010), informational and analytical materials of the Federation of Trade Unions of Ukraine "On the status of reforms in paid labor" and my own researches (N. Mitsenko (2016, 2017), D. Riznyk (2017).

The generalization of domestic and foreign literature allows to distinguish approaches to the consideration of labor motivation as: the process of influence on personnel for the formation and transformation of the needs of workers into the necessary result of labor activity; the type of management activity through the formation of a motivational field; function (mechanism) of personnel management; psychological and motivational factor; a combination of factors that determine the behavior of the employee; a combination of incentives and motives, etc., to identify its main components for detailed characterization and evaluation in order to provide in-depth study and to formulate a system for managing the motivation of labor, taking into account sectoral peculiarities.

The theoretical study of the evolution of theories of motivation allows us to consider the motivation of labor as a system of tools, measures and controls that are used to create an enterprise motivational environment, appropriate external incentives and internal motives of highly efficient personnel work, its development and implementation of intellectual potential, the performance of functional duties and tasks, prevention of deviant behavior, quality customer service, which collectively provides for the achievement of goals and operation and development tasks of the company. Therefore, the management of labor motivation acts as a direction of personnel management and the enterprise in general, which is aimed at implementing tools and measures for the system of motivation to achieve the goals of effective development of the enterprise.

The role of the system of motivation and management of it are especially important at the enterprises of the service sector, in particular the sanatorium and resort complex, where through workers the direct contact of the enterprise with the consumers of services is provided, from them depends on the qualitative characteristics of the services and their perception by consumers, their satisfaction with the service.

The results of the analysis revealed that the macroeconomic environment of the enterprises functioning of the sanatorium and resort complex of Ukraine is ambiguous, characterized by both positive aspects and signs of a systemic crisis, which affects the formation of prerequisites for personnel management and motivation of labor.

The main negative tendencies are: reducing the number of enterprises and institutions of the sanatorium and resort complex, reducing the number of bed places and production capacity in general, reducing the number of employees and the extent of service population, increasing the cost of services and the resulting deterioration of the financial capacity of enterprises to stimulate labor. Today, the sanatorium and resort industry in Ukraine has no single structure and is dispersed among different ministries, departments, joint-stock companies, public organizations and other structures. In this regard, the development of the sanatorium direction as a separate component of the system of rehabilitation medicine in the state is unsystematically and isolated. In 2014-2016, the occupation of the Autonomous Republic of Crimea was one of the factors that affected the network of 
facilities providing services in the sanatorium and resort services market and, accordingly, reduced the number of people recovered in these institutions.

To the systematic development of the investigated branch complex does not contribute the presence of imbalances in the regional markets of sanatorium and health and wellness services. On the territory of Ukraine there are 6 clusters according to the level of development of sanatorium and resort facilities:

1) Donetsk, Ivano-Frankivsk (climatic, balneological resorts), Kiev (climatic, balneological), Kharkiv (balneological) regions;

2) Zhytomyr, Rivne, Ternopil, Chernivtsi regions;

3) Kirovograd, Luhansk, Khmelnytsky regions;

4) Volyn, Sumy, Cherkasy, Chernihiv regions;

5) Dnipropetrovsk, Zaporizhia (climatic, balneological), Mykolaiv (climatic), Odessa (climatic, balneological), Kherson (climatic, balneological) regions;

6) Vinnytsia (balneological), Zakarpattia (balneological), Lviv (balneological), Poltava (balneological) regions, Kyiv (Figure 1), L. Galkiv, O. Sorochak (2017).

Revealed positive tendencies - factors of qualitative influence on the efficiency of personnel motivation management of the enterprises personnel: increase of income volumes from services rendering, growth of assets and working capital; modernization of the material and technical base of individual enterprises (sanatoriums); improvement of the qualitative characteristics and competitiveness of services.

Not less important is that within the sanatorium and resort complex motive mechanisms are also formed. Technological, financial, and information connections between the enterprises of the sanatorium and resort complex determine the interdependence of the work results of individual enterprises, and, consequently, the results of the their personnel work, and contribute to the formation of specific forms of stimu- lation at sectoral or regional levels. It is the producers of sanatorium and resort services who are interested in effective cooperation with tour operators and travel agents, since together they form a tourist product and sell it. Therefore, such enterprises create special programs for cooperation with intermediaries, including measures to encourage individual employees.

Certainly, the further development of the sector enterprises is largely determined by both high-quality staffing and the efficiency of the staff work and is directly related to the proper motivation of labor. In this context, it is important to understand the motivational mechanisms of the behavior of the enterprises personnel of the sanatorium and resort complex, as the main specifics of work in sanatoriums and institutions of the corresponding type, as one of the most labor-intensive in the recreational and tourist area, is its unskilled nature, low wages, a relatively long working week from a special schedule and a working regime, V. Semenov (2015). Accordingly, the low efficiency of the work of the staff of the sanatorium and resort enterprise leads to the low efficiency of the enterprise itself and the tourist cluster as a whole.

The specific characteristics of the enterprises personnel motivation of the tourist and recreational complex are determined by the peculiarities of their functioning, the functions performed and the socio-economic role in meeting the needs of consumers in the treatment, recreation and rehabilitation. Such features are the need to provide a wide range of services; non-standard regimes and the creative nature of labor; the high role of its social orientation, informal and non-material factors of social and labor relations; dependence on service quality standards (Figure 2).

On the basis of their consideration and clarification of the key subjects of motivation, the conceptual principles of labor motivation management

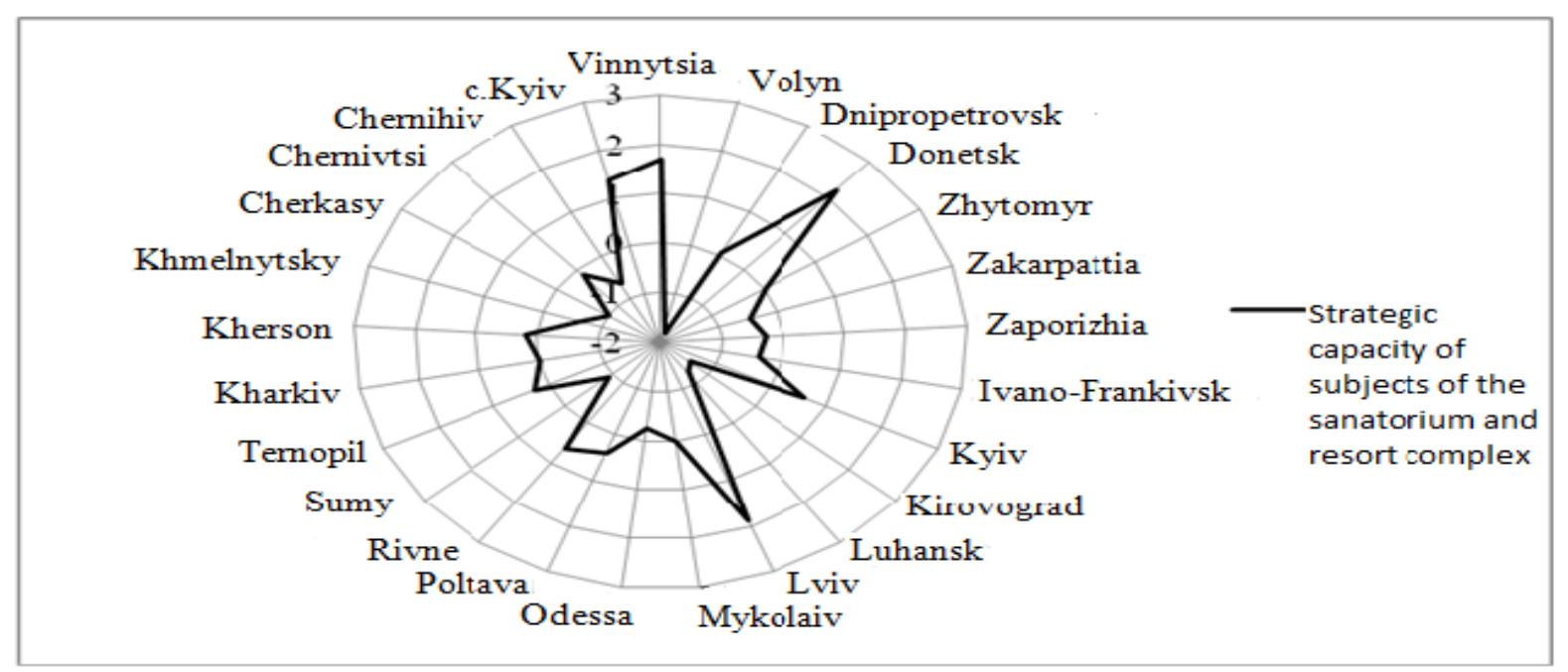

Figure 1. Distribution of Ukraine regions by results of statistical assessment of subjects development potential of the sanatorium and resort complex 


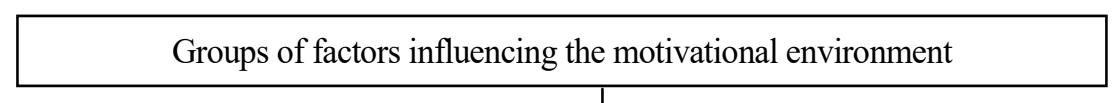

\begin{tabular}{|c|c|c|}
\hline \multicolumn{2}{|c|}{ Groups of factors influencing the motivational environment } & nent \\
\hline $\begin{array}{l}\text { The specifics of social and labor } \\
\text { relations, employment, conditions and } \\
\text { working regimes }\end{array}$ & $\begin{array}{l}\text { Perspectives and directions of } \\
\text { innovative development of } \\
\text { enterprises of the branch }\end{array}$ & $\begin{array}{l}\text { The processes of ensuring the } \\
\text { competitiveness of the enterprises of } \\
\text { the industry and their services }\end{array}$ \\
\hline & $\downarrow$ & 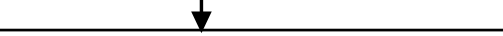 \\
\hline \multicolumn{3}{|c|}{$\begin{array}{l}\text { - } \quad \text { specific conditions and working regimes; } \\
\text { - lower level of specificity of the results of work, their creative character; } \\
\text { - } \quad \text { wide variability of the main and related services provided to consumers; } \\
-\quad \text { the high role of informal factors in the social and labor sphere; } \\
-\quad \text { significant social orientation of the sanatorium and resort area; } \\
-\quad \text { multi-stage interaction of personnel with service users and high dependence on compliance with service standards, } \\
\text { performance of customer service process as part of a product (service); } \\
-\quad \text { lower role of technical and technological base and higher non-material factors; } \\
-\quad \text { interaction of enterprises of the industry, the state, financial and social insurance funds in order to increase the level of } \\
\text { accessibility of services for the population; } \\
-\quad \text { dependence of business on the introduction of medical, technical, medical and technological, etc. innovations }\end{array}$} \\
\hline
\end{tabular}

\begin{tabular}{|c|c|c|}
\hline \multicolumn{3}{|c|}{$\begin{array}{l}\quad \text { Key motivational subjects: } \\
\text { - } \\
\text { - } \text { promotion of high quality and compliance with service standards; } \\
\text { - } \text { satisfaction and enthusiasm for work; } \\
-\quad \text { psychological motivation, spiritual needs and needs of employees in communication; } \\
-\quad \text { active and effective communication with consumers; } \\
-\quad \text { interbranch mobility of staff; } \\
\text { - innovative activity of personnel, activity on the implementation of author programs and methods of treatment, customer } \\
\text { service; } \\
-\quad \text { ability to strategize and form a business model for the operation and development of a tourism and recreation complex } \\
\text { enterprise }\end{array}$} \\
\hline & $\downarrow$ & \\
\hline Internal motivation & Economic motivation & Administrative motivation \\
\hline$\downarrow$ & $\downarrow$ & $I$ \\
\hline $\begin{array}{l}\text { - implementation of institutional } \\
\text { factors of labor motivation and the } \\
\text { contribution of each employee to } \\
\text { the results of work; } \\
- \text { harmonization of labor } \\
\text { motivation and implementation of } \\
\text { socially responsible behavior of the } \\
\text { enterprise; } \\
-\quad \text { harmonization of the } \\
\text { motivation of labor and the mission } \\
\text { of enterprises in the treatment and } \\
\text { rehabilitation of the population }\end{array}$ & $\begin{array}{l}\text { - orientation of incentives to } \\
\text { increase the efficiency of the } \\
\text { formation and use of labor } \\
\text { potential; } \\
- \text { employment (management) in } \\
\text { integration projects in the market } \\
\text { of sanatorium and resort, health- } \\
\text { improvement, tourism services; } \\
-\quad \text { direct and indirect material } \\
\text { remuneration for the support of } \\
\text { innovative business development }\end{array}$ & $\begin{array}{l}\text { - development of partnership } \\
\text { relations between management and } \\
\text { subordinates; } \\
- \text { establishment of a system of } \\
\text { liability and penalties for } \\
\text { compliance with or non- } \\
\text { compliance with standards of } \\
\text { quality of business processes for } \\
\text { the provision of services } \\
-\quad \text { fair career advancement and } \\
\text { merit evaluation }\end{array}$ \\
\hline
\end{tabular}

Figure 2. Peculiarities of functioning and management of personnel, key subjects and components of labor motivation at enterprises of tourist and recreation complex 
at enterprises of the sanatorium and resort complex were improved, for which the characteristics of motivation are supplemented: within the internal component - the introduction of institutional factors of labor motivation and the contribution of each employee to the results of work, the coordination of motivation and realization of the mission and socially responsible behavior of the enterprise; within the economic framework - the orientation of incentives to increase the efficiency of the formation and use of labor potential, employment in integration projects in the market of sanatoria and resort, medical and recreational, tourist services, direct and indirect material remuneration for supporting innovative business development; within the administrative framework - the development of partnership relations between the leadership and subordinates, the establishment of a system of liability and penalties for observing standards of quality of business processes of service delivery, fair career advancement and evaluation of employee merit.

In the process of analysis and in order to assess the state and effectiveness of the labor motivation management at the enterprises of the sanatorium and resort complex, a sociological survey of 83 respondents (18 doctors, 18 medical personnel, 24 administrative staff and 23 personnel) was conducted by questionnaires. It allowed to identify the types of work motivation used in the enterprises of the sanatorium and resort complex, to specify the substantive and content characteristics of the labor motivation, to determine the level of employees satisfaction with the motivation of labor, to identify problems and limitations in the management of motivation. The majority of respondents $(97,6 \%)$ relate qualitative and effective motivation of work with the creation of a motivational environment at enterprises and realize that effective management of labor motivation can ensure the growth of the effi- ciency of the functioning of enterprises of the sanatorium and resort complex (Figure 3).

To provide the economic characteristics of personnel motivation, 15 enterprises of the sanatorium and resort complex of Ukraine were investigated: PJSC "Sanatorium "Rai-Olenivka", PJSC "Sanatorium Moshnogirya", PJSC "Sanatorium "Smerichka", PJSC "Sanatorium-hotel complex "Dnipro-Beskyd", PJSC "Clinical sanatorium "Poltava-Crimea", PJSC "Children's health-sanatorium complex "Niva", PJSC "Joint enterprise "Sanatorium Poltava", PJSC "Truskavetskurort", PJSC of medical and recreational facilities "Mirgorodkurort", LTD "Sanatorium complex "Derenivska kupil", LTD "Sanatorium "Borisfen", PJSC "Treatment and health complex "Aivazovske", PJSC of medical and health institutions of trade unions of Ukraine "Ukrprofozdorovnytsia", PJSC "Kakhovka children's recreation camp "Lisova kazka" and PJSC "Children's recreation camp "Olympus". The analysis allowed to reveal the trends observed in the vast majority of the investigated enterprises: the reduction of personnel caused by the general socio-economic situation in Ukraine, the decline of the national currency and the decline in the welfare of the population; reduction of labor costs; reduction of the size of the fund of additional wages; insignificant level of payables on payroll calculations $(1,89 \%)$; the distinction of the economic component as the main component of motivation, which is important for all categories of enterprises personnel.

The questionnaire survey revealed that for doctors and nursing staff, the level of remuneration is slightly lower in the context of labor motivation compared with administrative and service staff; For employees involved in providing recreational and recreational services, high motivating factors are professional self-realization, raising the level of qualification and comfortable working conditions;

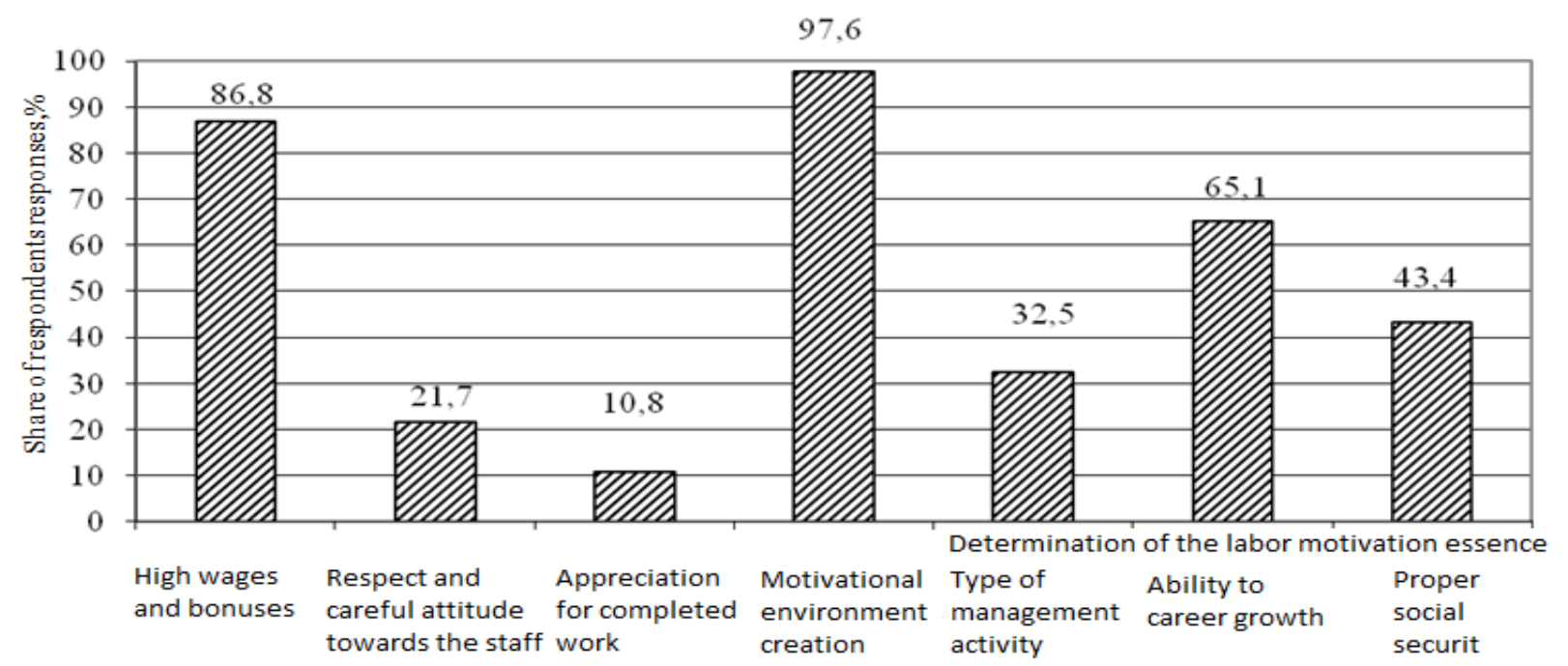

Figure 3. Results of respondents' survey on understanding the essence of motivation of work 


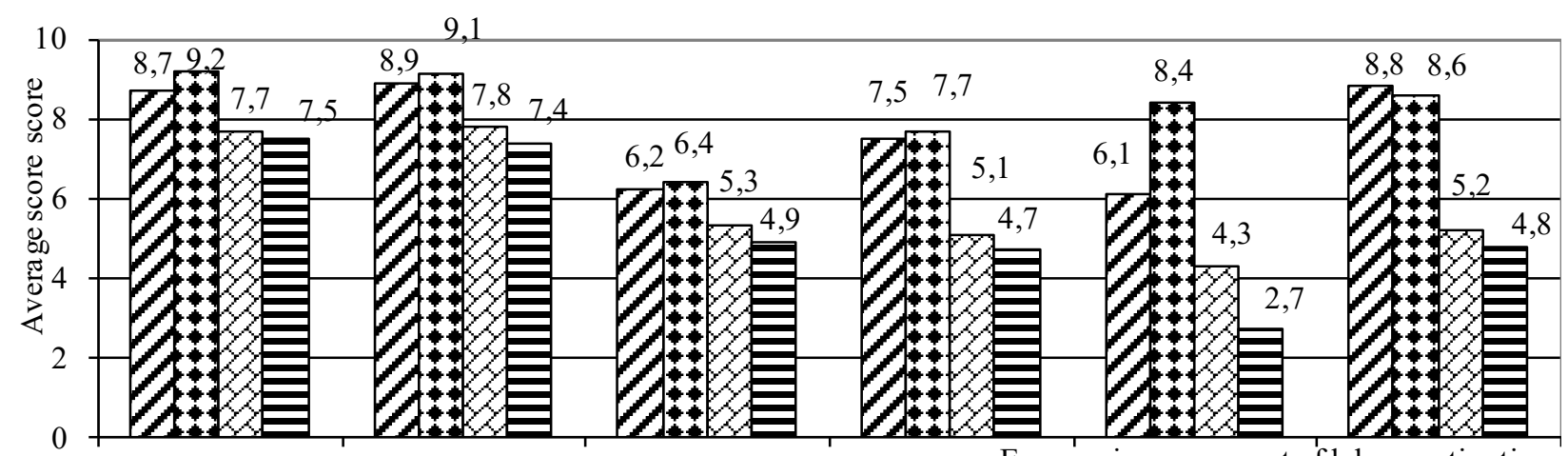

Economic component of labor motivation

\begin{tabular}{|c|c|c|c|c|c|}
\hline $\begin{array}{c}\text { Relevance to the } \\
\text { level of } \\
\text { remuneration }\end{array}$ & $\begin{array}{l}\text { Availability of a } \\
\text { flexible and } \\
\text { effective system } \\
\text { of material } \\
\text { incentives }\end{array}$ & $\begin{array}{l}\text { Consistency of } \\
\text { payment and } \\
\text { working } \\
\text { conditions }\end{array}$ & $\begin{array}{c}\text { Presence of } \\
\text { motivation for the } \\
\text { development of } \\
\text { intellectual and } \\
\text { laborpotential }\end{array}$ & $\begin{array}{l}\text { Motivation to } \\
\text { participate in } \\
\text { integration } \\
\text { projects }\end{array}$ & $\begin{array}{l}\text { Motivation for the } \\
\text { introduction of } \\
\text { innovations }\end{array}$ \\
\hline
\end{tabular}

\begin{tabular}{|l|l|l|}
\hline Doctors $\quad$ Administrative staff $\square$ Middle medicalstaff $\square$ Staff \\
\hline
\end{tabular}

Figure 4. Results of the respondents' survey on the assessment of the economic component of labor motivation (by category of staff)

high value in the motivation of the staff work is providing benefits and discounts, free-of-charge recreation; It is important for the high-quality work of middle medical personnel to be satisfied by direct managers (Figure 4).

In most aspects of administrative motivation, the highest level of satisfaction was observed in a group of administrative staff, and the lowest - the average medical and service personnel of enterprises. The level of employees internal motivation is high. The information obtained provides an opportunity to justify addressing measures of motivation for each category of employees.

The theoretical researches of modern fundamental works of scientists on the problems of personnel motivation management of enterprises allows us to conclude that today, before the leadership of many Ukrainian enterprises, there was a problem of substantiation of the motivation system for different categories of employees in order to maximally use their intellectual-personal potential for enterprise development and achievement of goals in the market of activity.

However, for the development of motivation systemf, the effectiveness of the existing system of motivation management should be evaluated, for which we used the results of employees sociological survey of enterprises and a system of evaluation indicators, grouped according to the main components of motivation (Table 1).

The value of integral indicators for individual components of efficiency was determined as the weighted average, and the generalizing integral coefficient - as the average geometric of them (Figure 5).
Taking into account the obtained results, it has been established that the greatest influence on the integral factor of the labor motivation management efficiency has internal motivation $(0,350)$; the economical $(0,296)$ and administrative $(0,289)$ components are almost identical to the integral indicator; among the parameters of the effectiveness of labor motivation, almost all are at the level of $0,05-0,06$, which indicates a relatively uniform impact on the general state of labor motivation management, so they all need to be included in the complex. Promising in the context of increasing the effectiveness of labor motivation management are the following motivations, such as the quality of the system of rules and regulations that workers must adhere to; development of partnerships between managers and subordinates; availability and fairness of the established system of responsibility for compliance with business process standards; the connection of the labor stimulation and the socially responsible behavior of the enterprise personnel (in aggregate, by $24,8 \%$, determine the effectiveness of motivation management).

Considering the importance of the impact on the final results of management and the development of enterprises, systematic, complex, and complexity of the labor motivation at the enterprises of the sanatorium and resort complex, it is necessary to build a rational management system for it, the internal elements of which are the subjects and objects of management, management tools, resource and infrastructure support, institutional-legal, normative-methodical and organizational basis, communication-psychological means (Figure 6). Such a system should take into 
Table 1

Results of the respondents' survey on the effectiveness of management of labor motivation at the enterprises of the sanatorium and resort complex (on the main components of motivation)

\begin{tabular}{|c|c|c|}
\hline $\begin{array}{l}\text { Components } \\
\text { of motivation }\end{array}$ & Evaluation parameters & $\begin{array}{c}\text { Obtained } \\
\text { values }\end{array}$ \\
\hline \multirow{6}{*}{ 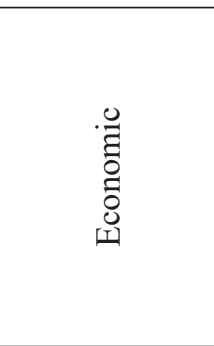 } & $\begin{array}{l}\text { Relevance of the level of remuneration, reasonableness of the system of rates and official } \\
\text { salaries }\end{array}$ & 0,614 \\
\hline & The formation of a flexible and effective system of material labor stimulation at the enterprise & 0,467 \\
\hline & $\begin{array}{l}\text { Coherence of the system of remuneration with the intensity, complexity and the final } \\
\text { results of labor }\end{array}$ & 0,681 \\
\hline & The presence of motivation employees to develop their own intellectual and labor potential & 0,627 \\
\hline & Level of motivation of employees to participate in integration and inter-industry cooperation & 0,304 \\
\hline & A measure of employee motivation for the creation and implementation of innovations & 0,461 \\
\hline \multirow{6}{*}{ 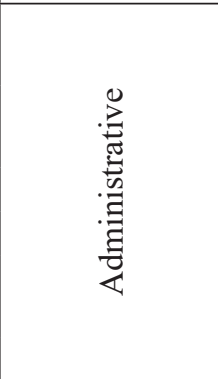 } & $\begin{array}{l}\text { The fairness and rationality of the organizational structure of enterprise and personnel } \\
\text { management }\end{array}$ & 0,792 \\
\hline & $\begin{array}{l}\text { The effectiveness of the company's coordination of the activities of the personnel using } \\
\text { regulatory documents (orders, instructions, regulations, etc.). }\end{array}$ & 0,845 \\
\hline & The quality of the system of rules and regulations that employees must adhere to & 0,819 \\
\hline & Development of partnership relations between managers and subordinates & 0,752 \\
\hline & $\begin{array}{l}\text { The existence and fairness of the established system of responsibility for compliance with } \\
\text { business process standards }\end{array}$ & 0,572 \\
\hline & \begin{tabular}{|l} 
Possibility of participation (involvement) of personnel in management processes \\
\end{tabular} & 0,781 \\
\hline \multirow{6}{*}{ 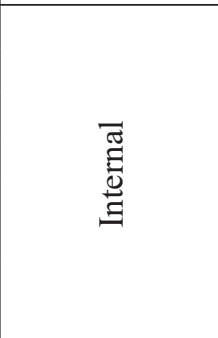 } & Favorable social and labor environment & 0,905 \\
\hline & Level of humanization and socialization of labor & 0,811 \\
\hline & Coherence of the goals of enterprise development and work of personnel & 0,681 \\
\hline & Level of intellectualization and enrichment of labor & 0,619 \\
\hline & $\begin{array}{l}\text { Communication of stimulation of labor and socially responsible behavior of the enterprise } \\
\text { personnel }\end{array}$ & 0,779 \\
\hline & $\begin{array}{l}\text { The level of influence on the labor behavior of the implementation of the public mission of } \\
\text { treatment and rehabilitation of the population }\end{array}$ & 0,871 \\
\hline
\end{tabular}

account the specifics of enterprises of different sizes, specialization, resource capabilities, personnel composition and structure.

It should also be taken into account that the effectiveness of the system for managing labor motivation at the enterprises of the sanatorium and resort complex will increase significantly in the conditions of forming a set of instruments and tools that will be oriented towards the main groups of personnel, which necessitates the details of the factors of motivation for physicians, secondary medical, administrative and servicemen the staff. At the same time it is necessary to ensure coordination of the tools of motivation with a strategic vision of the role of a certain category employee in ensuring the development of the enterprise spa resort.

Appropriate strategic approaches to motivating work of certain categories of staff are recommended:

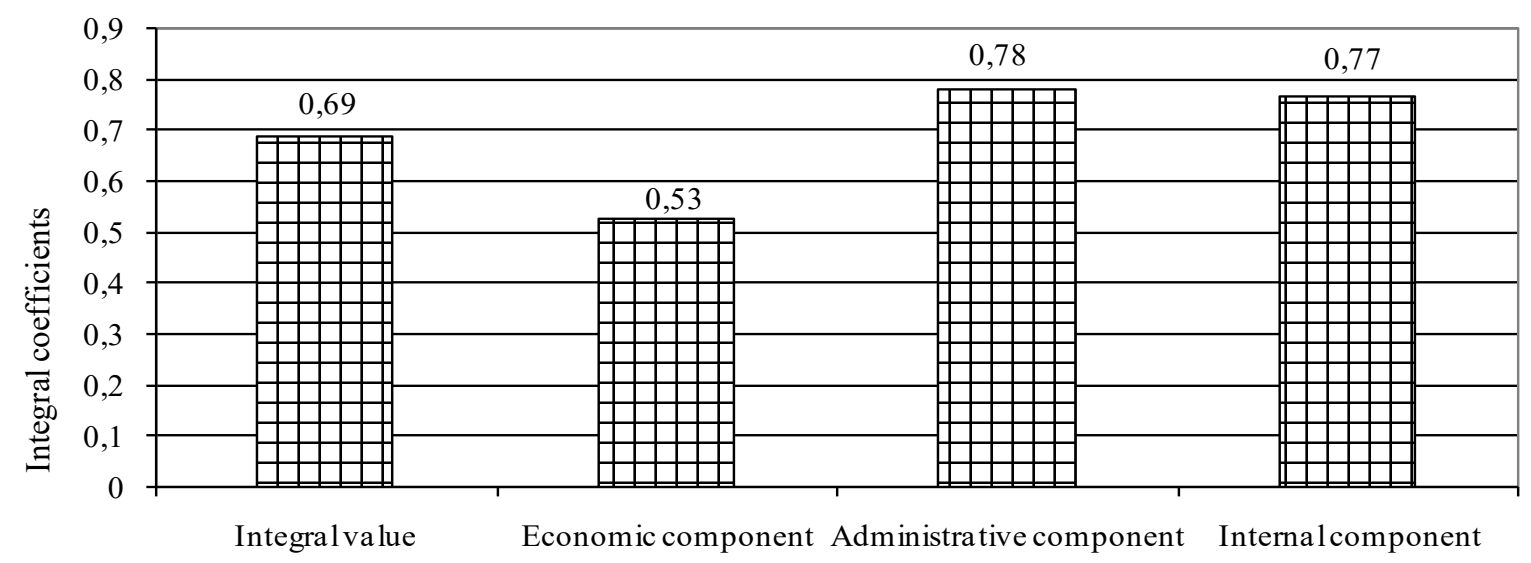

Figure 5. The value of the integral coefficient of labor motivation management efficiency in the context of its components at the enterprises under study 
for doctors - motivation to increase professionalism and devotion to the cause - can be realized through the establishment of a labor remuneration system according to the integral coefficients (in accordance with the group of significance and the category of employee's competitiveness) (economic component); expanding the participation of leading doctors in the management of enterprise development, adoption of key financial and economic decisions (administrative component); formation of high level of mobility and prestige of the higher medical personnel in the sanatorium-resort area (internal component); for administrative personnel - the motivation to develop innovative competitiveness of staff - can be implemented through the introduction of coefficients of increase in wages for the innovation of business processes; formation of bonus systems for the results of functioning and development of sanatorium and resort complex facilities (economic component); the inclusion of key management personnel in the supreme bodies of business management and control, the provision of a share in ownership; monitoring of the evaluation of efficiency at all levels of the management organizational structure (admin-

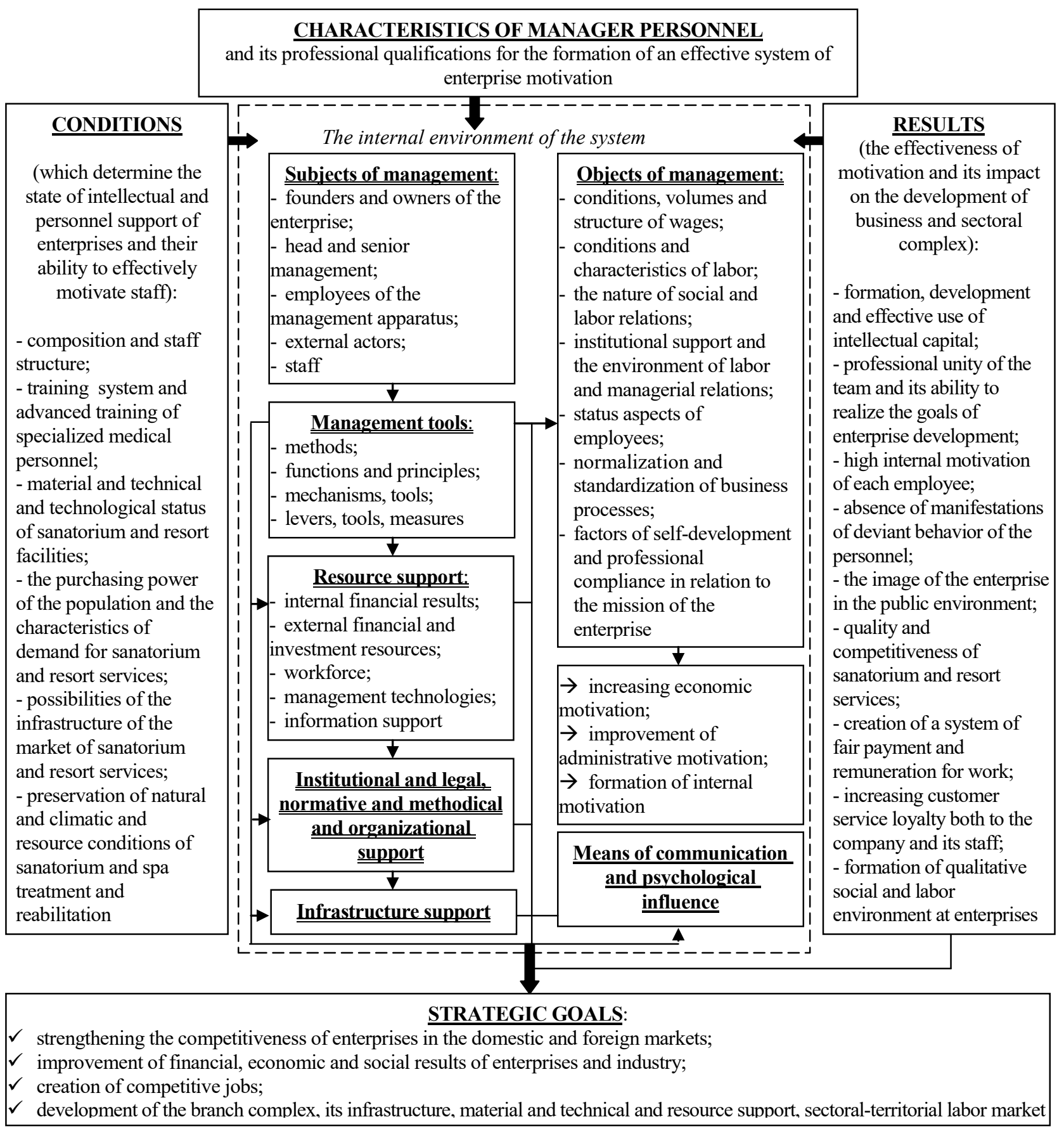

Figure 6. Conceptual characteristics of the modern management of enterprises motivation system of the sanatorium and resort complexy 
istrative component); realization of PR-programs on development of enterprises prestige and social responsibility in the territory of their functioning, including the role of management personnel (internal component);

for middle medical personnel - motivation for the formation of professional competitiveness - can be realized through the introduction of a categorically-professional network for the payment of labor to the average medical personnel (economic component); opportunities for participation in the formation and development of managerial personnel, the formation of a staff of professional managerial leaders, the construction of relations in the management system; introduction of a career development system (administrative component); the formation of an environment of satisfaction from the provision of health and recreation services and the results of labor (internal component);

for staff - motivation for training and development - can be realized through the reconciliation of the level of staff remuneration with the staff competitiveness; provision of privileges and discounts for rest and recreation (economic component); strengthening the standardization of functional responsibilities, tasks and work accomplished, minimizing "contact" with leaders, raising the level of "labor freedom" (administrative component); recognition of work results, improvement of conditions and modes of work and rest, introduction of technical and technological innovations in the service of business processes (internal component).

Conclusions. Motivation is one of the main factors in ensuring high-efficiency work, high-quality performance of officials, their professional qualification development, the formation and use of intellectual and personnel potential of the enterprise in general. The role of labor motivation is especially important at the enterprises of the sanatorium and resort complex, where through the employees the direct contact of the enterprise with the consumers of services is ensured, depending on them the qualitative characteristics of the services and their perception by the consumers, their satisfaction with the service. The study found that labor motivation is generally seen as a process of impact on staff, type of management, psychological and motivational factor, etc. At the same time, when forming the system of motivation of enterprises labor personnel it is necessary to take into account its specificity, conditioned, first of all, the peculiarities of their functioning, functions performed and socio-economic role in meeting the needs of consumers.

Labor motivation at the enterprises of the sanatorium and resort complex should be considered as a system of instruments, measures and management tools that are used to create a motivational environment at the enterprise, appropriate external incentives and internal motives for highly efficient personnel work, its development and implementation of intellectual potential, functional implementation responsibilities and tasks, prevention of deviant behavior, quality customer service, which collectively ensures the achievement of the goals and objectives of the function ionization and development of the enterprise.

Based on the results of our research on the peculiarities of labor motivation at the enterprises of the sanatorium and resort complex of Ukraine, we came to the conclusion that in order to construct an efficient system for managing labor motivation, it would be advisable to develop a well-balanced set of instruments and tools based on scientifically grounded results of research into the interests and motives of employees and active systems of motivation of their work, focusing on targeting and dynamism. The existing intellectual and personal potential of employees and the possibilities of its activation and effective use create the preconditions for enterprise effective development and formation of the its personnel loyalty system. The priority of the personnel motivation management directly determines the optimality of the use of available labor potential as the main lever of enterprise development.

To smooth the barriers and to ensure the acceleration of the adaptation of the management system of labor motivation to business processes, it is advisable for the enterprises to consistently pass the stages of the algorithm for the implementation of this system: assessment of the existing system of personnel motivation and the formation of the employees motivational profile; the identification of the relationship between the management of labor motivation and the efficiency and the current state of financial and economic activity of the enterprise; design of systems of economic, administrative and internal motivation, creation of personnel loyalty system; development of training system; introduction of coaching in active communications; institutional and organizational support for the implementation of the system; control of its results. As a means of monitoring the effectiveness and level of implementation of the labor motivation management system at the enterprises of the sanatorium and resort complex, it is recommended to use a card for stimulation and development of personnel, which involves monitoring and timely adjusting the parameters of such motivation areas as wages, promotion, recognition of personal achievements, training (development), social compensation, atmosphere in the team.

The synergetic effect of improving the efficiency of labor motivation management at the enterprises of the sanatorium and resort complex is manifested not only in the growth of quality and labor productivity, but also in improving all the parameters of the efficiency of the enterprises operation, including the positive socio-economic effect for the positioning of enterprises. 


\section{References:}

1. Bogynia D. P., Semikina M. V. (2003). Mental labor factor: problems of theory and practice. K.: Storm, $382 \mathrm{p}$.

2. Grinyova V. M., Gruzina I. A. (2007). Problems of motivation of the personnel of enterprise. Kharkiv: VD "Inzhek", 184 p.

3. Kolot A. M., Daniuk V. M., Petyuch V. M. (2017). Decent work: imperatives, Ukrainian realities, mechanisms of provision. K.: KNEU, $504 \mathrm{p}$.

4. Lobanova T. N. (2018). Motivation and promotion of work. M.: Yurait, $482 \mathrm{p}$.

5. Nyzhnik V. M., Harun O. A. (2011). Mechanism of motivation of high-performance work of personnel of enterprises. Khmelnytsky: KhNU, 210 p.

6. Parsyak V. N. (2003). Motivational management in the field of small business. Kherson: OLDI-Plus, 186 p.

7.Potyomkin L. M. (2011). Efficiency of the functioning of food enterprises: motivation of the personnel. Odesa: Palmyra, $243 \mathrm{p}$.

8. Semikina M. V. (2003). Motivation of competitive labor: the theory and practice of regulation. Kirovograd: PIC, $426 \mathrm{p}$.

9. Handii O. O. (2010). Management of the personnel of the enterprise: conceptual definition and mechanisms of development. Lugansk: SNU, $240 \mathrm{p}$.

10.Riznik D. V., Mitsenko N. G. (2017). Effective motivation of labor as a basis for management of the personnel of the enterprise. Bulletin of Lviv Economic and Trade University, 53, 90-95.

11. Mitsenko N. G. (2016). Motivational mechanism of enterprise labor potential management. Theoretical, methodological and practical foundations of human resources management. Riga: "Landmark" SIA, 210 p. (144-153).

12.Riznik D. V. (2016). The management system of labor motivation of the sanatorium complex in Ukraine. International Research Journal, 6(48), 76-79.

13. Galkiv L. I., Sorochak O. Z. (2017). Statistical typology and analysis of the activities of institutions of sanatorium and resort area. Effective economy, 11. UR : http://www.economy. nayka.com.ua/?op=1\&z=5851

14.Semenov V. F., Necheva N. V. (2015). Efficiency of motivation of work of labor resources of enterprises of sanatorium-resort complex. Problems and prospects of entrepreneurship development, 2(9), 127-133. 